\title{
Characterization of a Novel Specific Mouse Monoclonal Antibody Targeted to Envelope Protein E1/E2 of Hepatitis C Virus
}

\author{
Iman Touni *, Shaimaa S.Sobieh * , Maha A.Hewedy ", A.A.Tabll **1 \\ *Department of Botany, Faculty of Women for Arts Science and \\ Education, Ain Shams University, Cairo and ${ }^{* *}$ Department of \\ Microbial Biotechnology, National Research Centre, Giza, \\ Egypt
}

\begin{abstract}
A EPATITIS $\mathrm{C}$ virus has been proven to be a major disease over the world and widely present in Egypt. The aim of this study was to propagate, characterize and test the reactivity of the hybridoma cell line (7G9) which produces a novel mouse monoclonal antibody (MoAb) targeting HCV E1/E2 envelope protein. The propagation of this hybridoma cell line (7G9) was generated using standard hybridoma technology. Isotyping of the generated mouse antibody was done by commercial ELISA kit. The reactivity of (7G9) was assessed by ELISA plates coated by HCV E1/E2 derived from cell lysate transfected by plasmid expressed HCV E1/E2. The generated monoclonal antibody (7G9) was found to be an IgM antibody with a kappa light chain. ELISA showed that (7G9) reacted with cell lysate expressed HCV E1/E2 and (7G9) presented no cross-reactivity with different antigens such as Brucella abortus, Salmonella typhi and Hepatitis B Virus (HBV) antigens. ELISA revealed high reactivity of (7G9) with HCV E1 (a.a. 315-323) antigen. Thus, the mouse monoclonal antibody (7G9) can be used for immunodiagnosis of $\mathrm{HCV}$ infection by detection of HCV E1/E2 antigens.
\end{abstract}

Keywords: Hepatitis C Virus - Envelope Protein E1/E2 - Hybridoma cell line (7G9)

Hepatitis C virus (HCV) is a major cause of liver disease and 3\% of the global population are estimated to be infected (Vieyers et al., 2014). In Egypt, HCV infections were recorded (Abdel Hamid et al., 2007) and remain a major health problem (Mohamoud et al., 2013). The serologic diagnosis of HCV is usually difficult due to the lack of a gold standard procedure (Araujo et al., 2011).In addition,the differentiation between acute and chronic cases for HCV is difficult depending on the present available serological assays as well as upon the symptoms and the clinical history of the patients. Also, the majority of acute infections are asymptomatic which develop to a chronic case unnoticed. Even detection of IgM is not sufficient to differentiate between acute and chronic HCV cases, sometimes produced in chronic cases and not always produced in acute cases (Lange and Sarrazin, 2010). The aim of this study was the propagation, characterization and evaluation of the reactivity of novel hybrid cell line (7G9) producing mouse monoclonal antibody, targeting HCV E1/E2 envelope protein to improve diagnostics.

${ }^{1}$ Corresponding Author Email : ashraftabll@yahoo.com 


\section{Materials}

Hybridoma cell line

The hybridoma cell line (7G9) targeting HCV E1/E2 was generated by Dr. Ashraf Tabll (2010) and was used in this study.

\section{Antigens}

1- Brucella abortus antigen and 2- Salmonella typhi antigen (Sal. O Group D Ag and Sal. Flagellar d Ag) by Becton, Dickinson and Company (Sparks, Maryland 21152 USA).

3- HBV antigen (HBc Ag coated plate with genetically engineered hepatitis B core antigen) by Enzygnost (Siemens Healthcare Diagnostics Products Gmbh Germany).

\section{Methods}

Revival and propagation of hybridoma cell line producing mouse monoclonal antibody $(M o A b)$

The hybridoma cell line producing mouse MoAb (7G9) was generated by hybridoma technology (Köhler and Milstein, 1975), using C57B1/6 mice immunized with a plasmid expressing the E1/E2 proteins of the HCV AD78 strain which was provided by Dr. Sergei Viazov (Essen Virology Institute, Germany).The plasmid was used to express the E1/E2 proteins of the HCV AD78 strain in HEK293 cells and the lysate from these cells were used for the in-house ELISA experiments (Tabll et al., 2013). The monoclonal antibody producing cells (Fig. 1) were propagated in DMEM medium supplemented with $20 \%$ fetal bovine serum, (1\%)L- glutamine, penicillin/streptomycin and HEPES. The supernatant of the culture was collected and tested for the presence of the HCV targeted monoclonal antibodies using in-house ELISA and the producing cells were cryopreserved (Ryan, 2004).

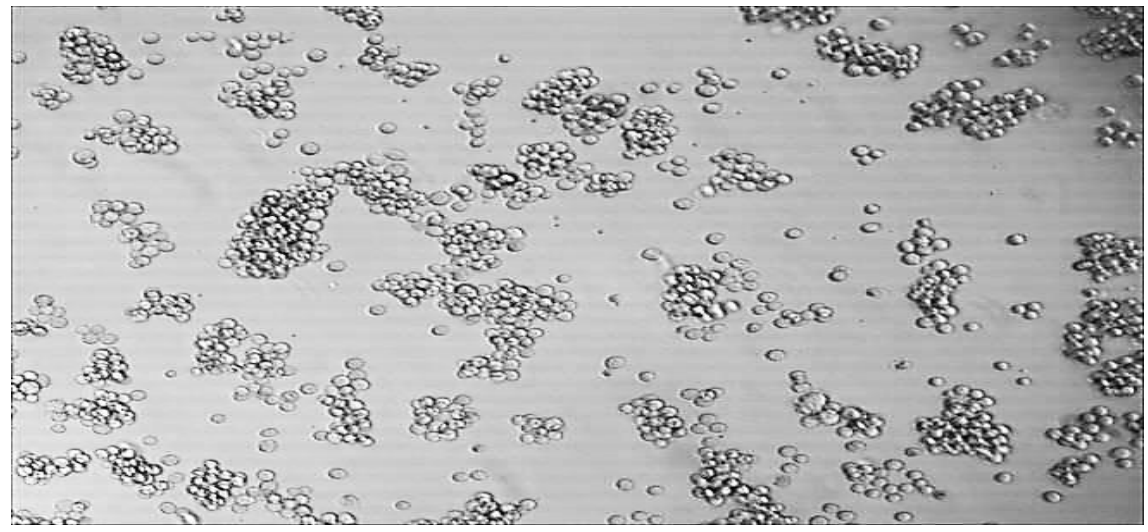

Fig. 1. The hybridoma cell line (7G9) producing monoclonal antibodies targeting HCV E1/E2 (100 x)

Egypt. J. Bot., Vol. 56, No. 3 (2016) 
Evaluation of the reactivity of the generated mouse MoAb (7G9) against the HCV E1/E2 transfected cell lysates by ELISA:

The in-house ELISA was conducted as previously described (Tabll et al., 2013). Briefly, ELISA plates were coated with lectin in carbonate/bicarbonate buffer and incubated overnight at room temperature. The plates were then blocked with blocking buffer and incubated overnight at $4{ }^{\circ} \mathrm{C}$, and washed (all washes were performed 4 times using PBS/T). Positive HCV E1/E2 cell lysate was added at 1:50 dilution in PBS $(100 \mu 1 /$ well $)$ and incubated overnight at $4{ }^{\circ} \mathrm{C}$. The plates were washed and the generated (7G9) mouse monoclonal antibody supernatant was added $(100 \mu \mathrm{l} /$ well).Human sera positive for $\mathrm{HCV}$ antibodies at 1:100 in dilution buffer were included as positive control and human sera negative for $\mathrm{HCV}$ antibodies and culture medium were used as negative controls. Incubations were carried out for $3 \mathrm{hr}$ at $37^{\circ} \mathrm{C}$ followed by washing and addition of conjugated anti-human peroxidase (KPL Inc, Gaithersburg, Maryland, USA) (100 $\mu 1 /$ well) for the human controls at 1: 5000 in dilution buffer and conjugated antimouse peroxidase (Sigma, USA) at 1: 5000 for mouse antibody and incubated for $1 \mathrm{hr}$ at $37^{\circ} \mathrm{C}$. After another washing step, the substrate ortho-phenylene diamine (one tablet OPD / $10 \mathrm{ml}$ citrate buffer with $10 \mu \mathrm{H} \mathrm{H}_{2} \mathrm{O}_{2}$ ) was added $(100 \mu \mathrm{l} /$ well) and incubated at room temperature for 5-15 min. The reaction was stopped using $3 \mathrm{M} \mathrm{HCl}(100 \mu \mathrm{l} / \mathrm{well})$ and the plate was read at $450 \mathrm{~nm}$ by ELISA reader (Labsystems,Model Multiskan EX)

Isotype determination of the mouse $\mathrm{MoAb}(7 G 9)$

The isotype was identified using the Pierce Rapid ELISA Isotyping Kit \#37503(3747N Meridian Rd, Rockford, IL 61101/USA).

Evaluation of the specificity of the mouse MoAb (7G9)

The evaluation was done using ELISA (Engvall and Perlmann 1971, El Awady et al., 2009) by coating ELISA plates with different antigens (Brucella abortus, Salmonella typhi and Hepatitis B Virus (HBV)) followed by blocking $(0.1 \%$ non-fat dry milk in carbonate / bicarbonate buffer) and incubation for $1 \mathrm{hr}$. at $37^{\circ} \mathrm{C}$, washing 3 times with PBS/T then addition of the monoclonal antidody (7G9) undiluted to the plates. Following a $2 \mathrm{hr}$.incubation at $37^{\circ} \mathrm{C}$, and washing, conjugated anti-mouse IgM labelled alkaline phosphatase (KPL/Kirgegaard and Perry Laboratories INC. 2 Cessna Court, Gaithersburg, Maryland 20879) was added at a dilution of 1:100 in $0.1 \%$ non-fat dry milk/ PBST and incubated for $1 \mathrm{hr}$. at $37^{\circ} \mathrm{C}$. The substrate para-nitrophenylphosphate (p-NPP) \# S0942(Sigma Aldrich /USA) was then added at a dilution of $1 \mathrm{mg} / \mathrm{ml}$ in diethanolamine buffer and incubated for $30 \mathrm{~min}$ at $37^{\circ} \mathrm{C}$. The reaction was ended by using the stopping buffer $3 \mathrm{M} \mathrm{NaOH}$ and the plates were measured at $405 \mathrm{~nm}$ using the ELISA reader.

Evaluation of the sensitivity of the mouse MoAb (7G9)

The sensitivity of the monoclonal antibody (7G9) was tested by coating an ELISA plate with serial dilutions $(15 \mu \mathrm{g} / \mathrm{ml}-7.5 \mu \mathrm{g} / \mathrm{ml}-3.75 \mu \mathrm{g} / \mathrm{ml}-1.88 \mu \mathrm{g} / \mathrm{ml}$ 
- $0.94 \mu \mathrm{g} / \mathrm{ml}-0.47 \mu \mathrm{g} / \mathrm{ml}-0.24 \mu \mathrm{g} / \mathrm{ml}$ ) of the peptide (HCV a.a. 315-323) E1 antigen, followed by using the in-house peptide-ELISA (Tabll et al., 2013)

\section{Results}

Detection of mouse MoAb in supernatants of cell line by ELISA

The tested monoclonal antibody (7G9) gave a high reactivity with an Optical Density (OD) value (2.6). The HCV human positive control gave an OD value of (1.7) whereas the HCV human negative control had an OD of (0.4) and the negative control (complete medium) had an OD value (0.08) (Fig 2.).

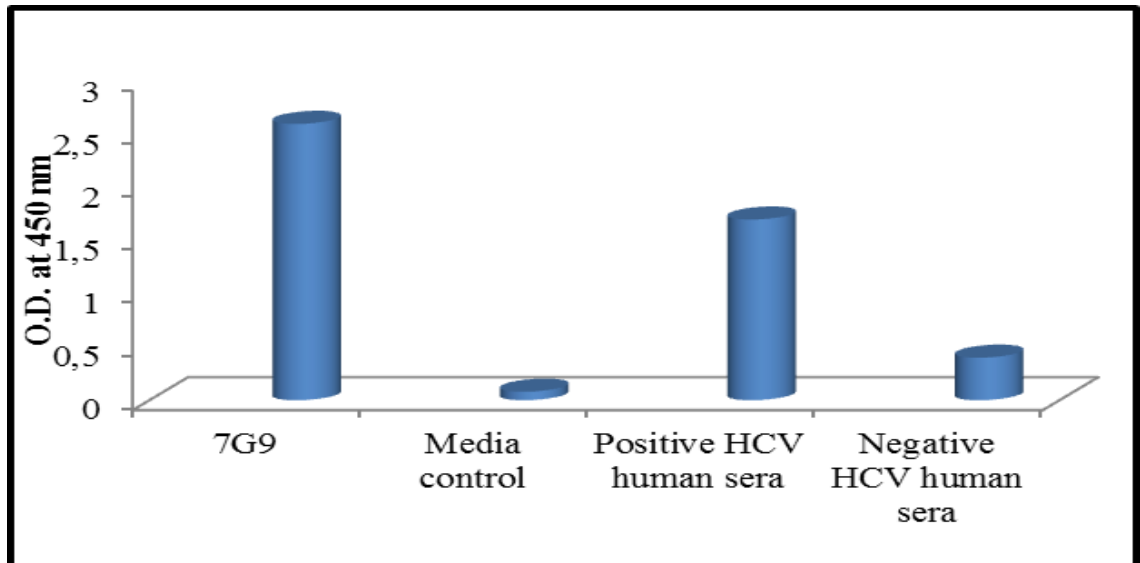

Fig. 2. Reactivity of the generated mouse monoclonal antibody (7G9)

Isotyping of the mouse MoAb

The tested mouse monoclonal antibody (7G9) had a heavy chain IgM and a kappa light chain (Fig. 3 )

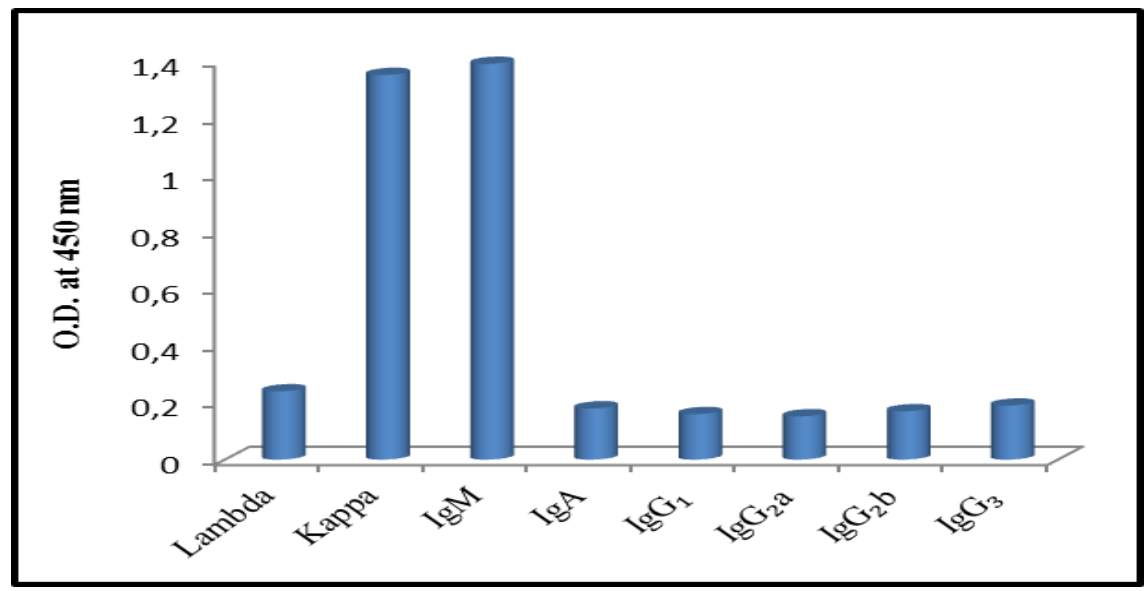

Fig 3 Isotyping of the generated mouse monoclonal antibody (7G9)

Egypt. J. Bot., Vol. 56, No. 3 (2016) 
Specificity

Brucella abortus, Salmonella typhi and HBV antigens were used to coat wells. No reactivity with both bacteria organisms and HBV was obtained. The positive control was a pool of HCV positive samples, the negative control was DMEM medium and the blank was PBS (Fig. 4.).

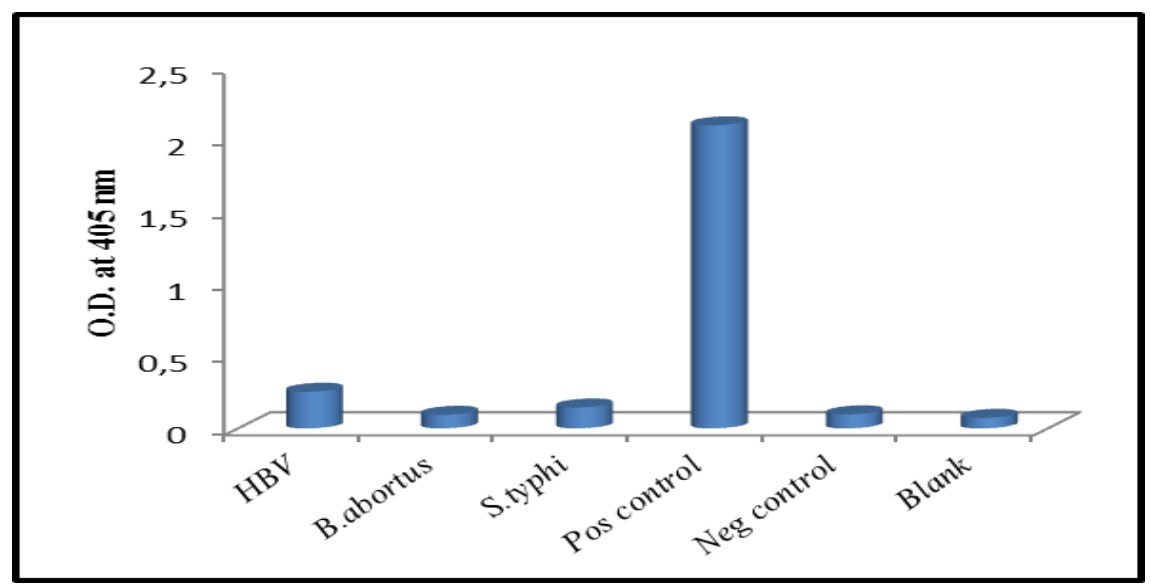

Fig. 4 Reactivity of the novel monoclonal antibody (7G9) towards Brucella abortus, Salmonella typhi and HBV antigens

Sensitivity limit of the mouse MoAb (7G9)

The sensitivity of the mouse monoclonal antibody (7G9) was detected till $2.00 \mu \mathrm{g} / \mathrm{ml}$ of the coated antigen, which was HCV E1 (a.a. 315-323) antigen (Fig. 5). This was a high dilution meaning that it was very sensitive.

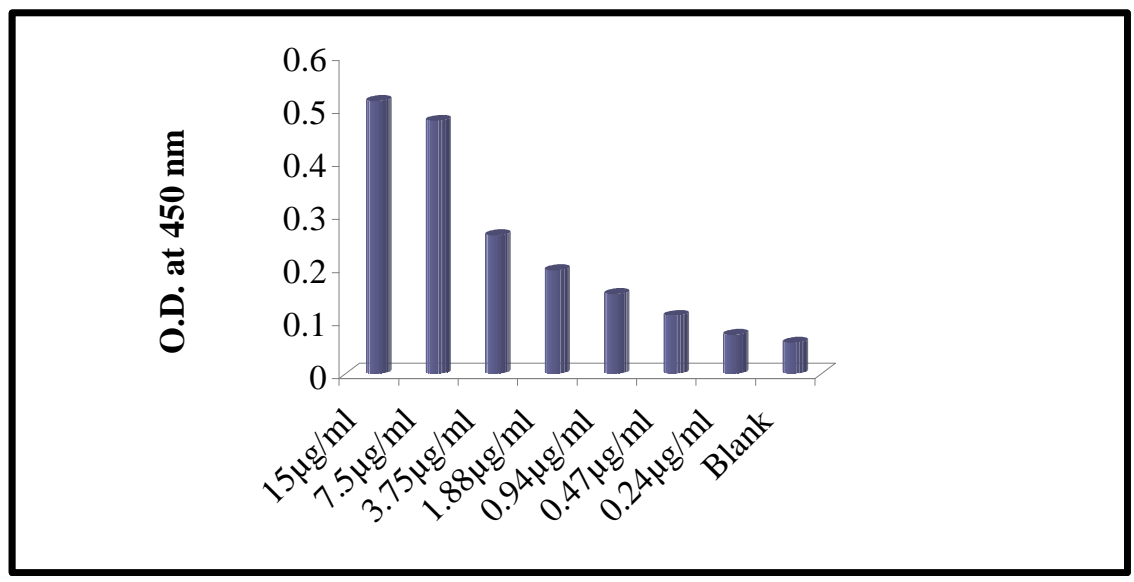

Fig. 5. Reactivity of the mouse monoclonal antibody (7G9) towards serial dilution of E1 antigen (envelope glycoproteins E1). 


\section{Discussion}

Production of mouse monoclonal antibodies by the hybridoma method (Köhler and Milstein 1975) showed the possibility of the fusion of antibody producing cells from mice with tumor cells to generate monoclonal antibodies. This was the first time to obtain unlimited production of a specific monoclonal antibody, which led to an immense benefit of therapeutic and diagnostic use of monoclonal antibodies. Although,the production of monoclonal antibodies started many years ago,still there are several hundred monoclonal antibodies to treat a broad range of conditions and others under evaluation, and a handful of therapeutics on the market (Madorsky Rowdo et al., 2015).

Hepatitis $\mathrm{C}$ virus $(\mathrm{HCV})$ is a major health problem worldwide. This virus infects more than 180 million people across the whole world (2-3\% of the world's total population) (Moradpour and Müllhaupt, 2015). HCV (genotype 4) is one of the main health problems particularly in Egypt. It infects $22 \%$ of its general population (El-Shabrawi and Hassanin, 2014). In the present study, we generated and propagated a hybrid cell line to produce mouse monoclonal antibody (7G9) targeting $\mathrm{HCV}$ envelope region. Isotyping of this antibody showed it to be isotype IgM and kappa chain. The generated antibody (7G9) showed good specificity where it did not react with Brucella abortus, Salmonella typhi or HBV antigens. The tested monoclonal antibody (7G9) showed also good sensitivity with HCV peptides only. The peptide used to test the sensitivity of the monoclonal antibody (7G9) was the envelope glycoprotein E1 (a.a. 315-323) antigen. The high sensitivity was detected till $2.00 \mu \mathrm{g} / \mathrm{ml}$ of the coated antigen. Several mouse monoclonal antibodies targeting HCV core and envelope regions are already known and these antibodies are mainly used for antigen detection (Cagnon et al., 2004, Tabll et al., 2008 and Shi et al., 2014).The monoclonal antibody (7G9) is targeted to the envelope glycoproteins E1 and E2.These envelope glycoproteins E1 and E2 are essential in the attachment and entry of the virus ( Sabo et al. ,2011).E2 causes not only viral attachment to the cell membrane at its entrance but enhances also the neutralizing antibodies in the host. The envelope proteins play a major role in attachment and entry of virions into the body (Mazumdar et al., 2011) and (Park et al., 2013). Moreover, although E2 is immunologically dominant and can hide the E1 epitopes, E1 causes specific antibody responses leading it to be a candidate to vaccine trials (Garrone et al., 2011). Further studies will be done on the evaluation of ELISA or Dot -ELISA for diagnosis of $\mathrm{HCV}$ based on detection of $\mathrm{HCV}$ envelope glycoprotein E1-E2 antigen in sera samples. Thus, this mouse monoclonal antibody (7G9) can be useful for HCV diagnosis based on antigen detection, as well, for studying the HCV vaccine development.

Acknowledgment: Our special thanks are due to Andreas Walker, Milena Lange and Sina Luppus, Essen virology institute, for their technical assistant. The production of hybrid cell line was carried out at lab of Dr. Sergei Viazov, Essen virology institute, Germany and was funded by DAAD for Dr. Ashraf Tabll

Egypt. J. Bot., Vol. 56, №. 3 (2016) 


\section{References}

Abdel-Hamid, M., El-Daly M., Molnegren, V., El-Kafrawy, S., Esmat, G., Strickland, G., Loffredo, C., Albert, G. and Widell, A. (2007) Genetic diversity in hepatitis $\mathrm{C}$ virus in Egypt and possible association with hepatocellular carcinoma. J. Gen. Virol., 88 (5), 1526-1531

Araujo, A.C., Astra Khantsera, I., Field, H. A. and Kamili, S. (2011) Distinguishing acute from chronic hepatitis $\mathrm{C}$ virus (HCV) infection based on antibody reactivities to specific HCV structural and nonstructural proteins . $J$ Clin Microbiol., 49 (1), 54-57

Cagnon, L., Wagaman, P., Bartenschlager, R., Pietschmann, T., Gao, T., Kneteman, N.M., Tyrrell, D.L., Bahl, C., Niven, P., Lee, S. and Simmen, K.A. (2004) Application of the trak-C HCV core assay for monitoring antiviral activity in HCV replication systems. J. Virol. Methods., 118 (1), 23-31

El-Awady, M.K., Tabll, A.A., El-Abd, Y.S., Yousif, H., Hegab, M., Reda, M., El Shenawy, R., Moustafa, R.I., Degheidy, N. and El Din, N.G. (2009) Conserved peptides within the $\mathrm{E} 2$ region of Hepatitis $\mathrm{C}$ virus induce humoral and cellular responses in goats. Virol. J, (6), 66

El-Shabrawi, M. and Hassanin F. (2014) Treatment of hepatitis B and C in children. Minerva Pediatr, 66 (5), 473-89

Engvall, E. and Perlmann, P. (1971) Enzyme-linked immunosorbent assay (ELISA).Quantitative assay of immunoglobulin G.Immunochemb., 8 (9): 871-874

Garrone, P., Fluckiger, A.C., Mangeot, P. E., Gauthier, E., Dupeyrot-Lacas, P., Mancip, J., Cangialosi, A., Du Chéné , I., LeGrand, R., Mangeot, I., Lavillette, D., Bellier,B.,Cosset, F.L., , Frederic Tangy,F., Klatzmann,D. and Dalba, C. (2011) A prime-boost strategy using virus-like particles pseudotyped for $\mathrm{HCV}$ proteins triggers broadly neutralizing antibodies in macaques. Sci. Transl. Med., 3, 94 94ra71

Köhler, G. and Milstein, C. (1975) Continuous cultures of fused cells secreting antibody of predefined specificity. Nature., 25 (6), 495-497

Lange, C. and Sarrazin, C. (2010) Hepatology : A Clinical Textbook, Chapter 12: Diagnostic Tests in Acute and Chronic Hepatitis C, $2^{\text {nd }}$ ed, Germany

Madorsky Rowdo, F.P., Baron, A., Urrutia, M. and Mordoh, J. (2015) Immunotherapy in Cancer: A Combat between Tumors and the Immune System; You Win Some, You Lose Some. Front Immunol., 6, 127 
Mazumdar, B., Banerjee, A., Meyer, K. and Ray, R. (2011) Hepatitis C virus E1 envelope glycoprotein interacts with apolipoproteins in facilitating entry into hepato- cytes. Hepatology, 54 , 1149-1156

Mohamoud, Y.A., Mumtaz, G.R., Riome, S., Miller, D. and Abu- Raddad, L.J. (2013) The epidemiology of hepatitis C virus in Egypt: a systematic review and data synthesis.BMC Infectious Diseases, 13, 288

Moradpour, D. and Müllhaupt, B. (2015) Hepatitis C epidemiology natural course and diagnosis. Rev. Med. Suisse., 11(471), 896-901

Park,J.H., HyeokJee, M., Kwona, O.S., Keuma, S.J. and Jang, S.K. (2013) Infectivity of hepatitis $C$ virus correlates with the amount of envelope protein E2: Development of a new aptamer-based assay system suitable for measuring the infectious titer of HCV. Virology, 439, 13-22

Ryan, J.A. (2004) General guide for Cryogenically Storing Animal cell cultures at www.level.com.tw/cell freezing protocol

Sabo, M.C., Luca, V.C., Prentoe, J., Hopkraft, S.E.,Keril J.,Blight, K.J.,Yi, M., Lemon, S.M., Ball, J.K., Bukh, J., Evans, M., Fremont, D.H., Michael, S. and Diamond, M.S (2011) Neutralizing monoclonal antibodies against Hepatitis C Virus E2 protein bind discontinuous epitopes and inhibit infection at a postattachment step.J.Virol., 85 (14), 7005-19

Shi, S., Yu, X., Gao, Y., Xue, B., Wu, X., Wang, X., Yang, Dand , Zhu, H. (2014) Inhibition of hepatitis $C$ virus production by aptamers against the core protein J. Virol. Feb. 88 (4), 1990-9.

Tabll, A., El Abd, Y., Bader El Din, N., El Shenawy, R., Abdelhafez, T., El Awady, M., El-Mohamady, H. and Viazov, S. ( 2013) Establishment of human clones producing neutralizing human monoclonal antibodies to the envelope E1/E2 protein of hepatitis $C$ virus by EBV immortalization of immune CD22+ B cells. Human Antibodies, 22, 55-65

Tabll,A., Khalil,S., El-Shenawy,R., Esmat,G., Helmy,A., Attallah,A.,and ElAwady,M. (2008) Establishment of hybrid cell lines producing monoclonal antibodies to a synthetic peptide from the $\mathrm{E} 1$ region of the hepatitis $\mathrm{C}$ virus. J. Immunoassay Immunochem., 29 (1), 91-10

Vieyres, G., Dubuisson, J. and Pietschmann, T. (2014) Incorporation of hepatitis C virus e1 and E2 glycoproteins: The Keystones on a Peculiar virion . Viruses., 6 (3), 1149-1187 


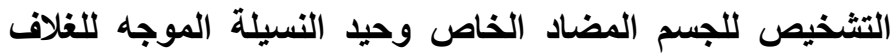

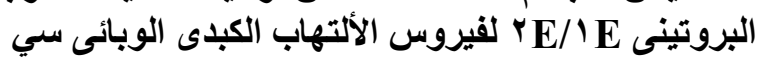

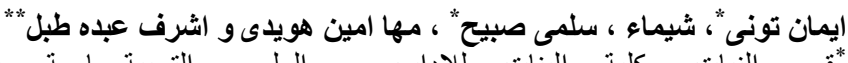

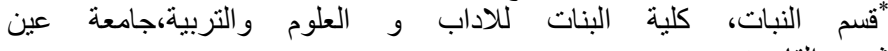

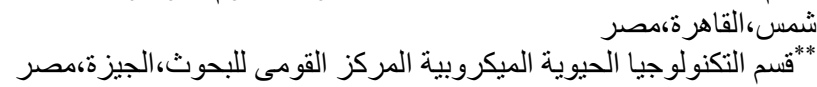

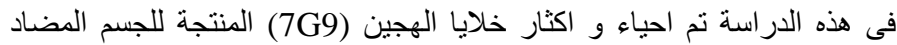

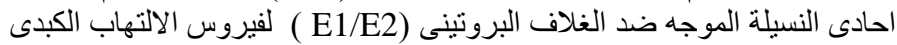

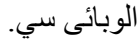

تم اختبار معلقات الهجين (7G9) و ادت نتائج اختبار الالبزا الى وجود الجسم

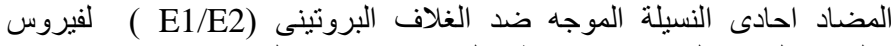

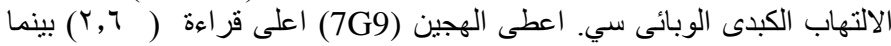

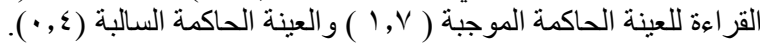

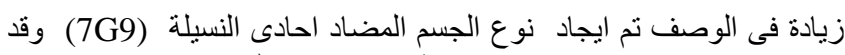

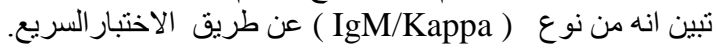

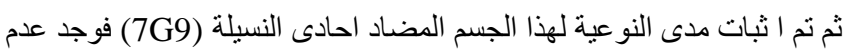
نشاطه مع فيروس الالتهاب الكبدى الوبائى بي و البروسيلا ابورتس والنيل السلمونيلا كما تم اختبار مدى الحساسية عن طريق تخفيفات متتالية لمولد المضاد

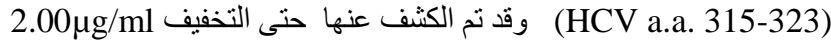

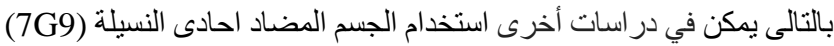

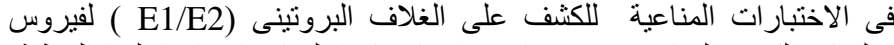

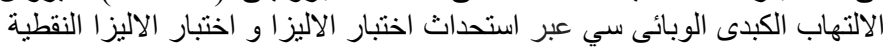
وكذللك، يمكن دراسة تطوير لقاح لفيروس الالتهاب الكبدى الوبائي سي. 